\title{
Mathematics Achievement: The Relationship between Student Engagement, Parental Involvement, and Peer Influence
}

Nora'asikin Abu Bakar, Ahmad Fauzi Mohd Ayub, Nor Aniza Ahmad, Sharifah Intan Sharina Syed Abdullah

To Link this Article: http://dx.doi.org/10.6007/IJARBSS/v11-i5/9973

DOI:10.6007/IJARBSS/v11-i5/9973

Received: 07 March 2021, Revised: 10 April 2021, Accepted: 29 April 2021

Published Online: 26 May 2021

In-Text Citation: (Bakar et al., 2021)

To Cite this Article: Bakar, N. A., Ayub, A. F. M., Ahmad, N. A., \& Abdullah, S. I. S. S. (2021). Mathematics Achievement: The Relationship between Student Engagement, Parental Involvement, and Peer Influence. International Journal of Academic Research in Business and Social Sciences, 11(5), 496-513.

Copyright: @ 2021 The Author(s)

Published by Human Resource Management Academic Research Society (www.hrmars.com)

This article is published under the Creative Commons Attribution (CC BY 4.0) license. Anyone may reproduce, distribute, translate and create derivative works of this article (for both commercial and non-commercial purposes), subject to full attribution to the original publication and authors. The full terms of this license may be seen at: http://creativecommons.org/licences/by/4.0/legalcode

Vol. 11, No. 5, 2021, Pg. 496 - 513

Full Terms \& Conditions of access and use can be found at http://hrmars.com/index.php/pages/detail/publication-ethics 


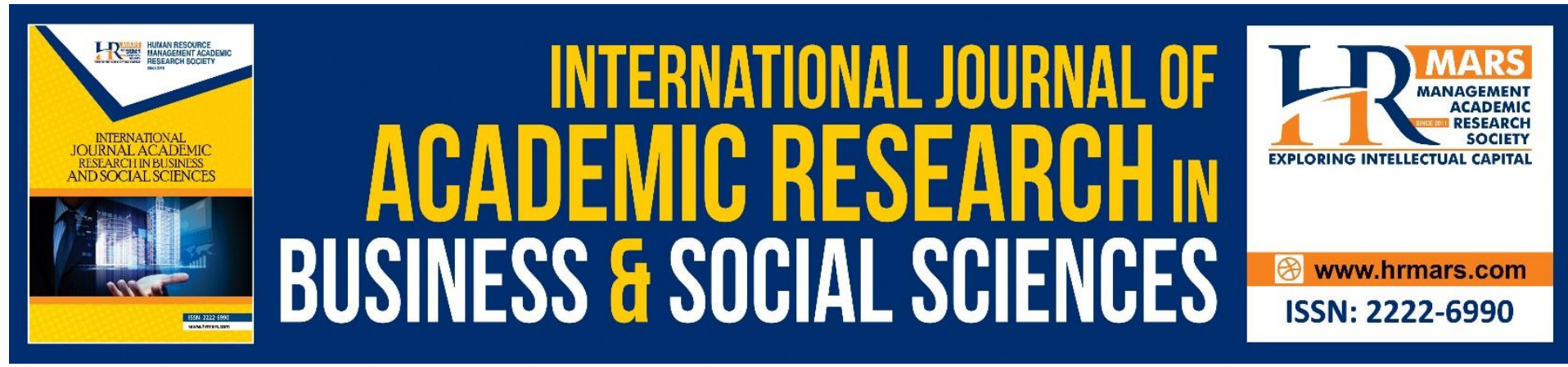

\title{
Mathematics Achievement: The Relationship between Student Engagement, Parental Involvement, and Peer Influence
}

\author{
Nora'asikin Abu Bakar ${ }^{1}$, Ahmad Fauzi Mohd Ayub², Nor Aniza \\ Ahmad $^{3}$, Sharifah Intan Sharina Syed Abdullah ${ }^{4}$ \\ ${ }^{1,2}$ Institute for Mathematical Research, Serdang, Universiti Putra Malaysia, ${ }^{1}$ Faculty of \\ Applied Science, Infrastructure University Kuala Lumpur, 2,3,4 Faculty of Educational Studies, \\ Serdang, Universiti Putra Malaysia \\ Email: afmy@upm.edu.my
}

\begin{abstract}
Mathematics is an important subject as a skill and foundation to further learning at the university level. In this regard, the engagement of students in the learning of mathematics is required so that mathematical knowledge and skills can be learned and mastered as much as possible. Previous study showed that student engagement, parental involvement, and peer influence affect mathematics achievement at a university. The purpose of this is to examine the relationship between mathematics achievement, the three aspect of student engagement, parental involvement, and peer influence. Data were collected from a total sample of 284 undergraduate students at a private university in Malaysia. Descriptive statistics and multiple regression analyses were used to analyse the data. Mathematics achievement was positively related to cognitive engagement and affective engagement, while behavioural engagement did not affect their achievement. Parental involvement and peer influence, on the other hand, are negatively related with mathematics achievement. More studies that concentrated on the relationship between parental involvement, peer influence, and student engagement in the future are encouraged to establish students' engagement in mathematics learning that vital to increase their mathematics achievement. A qualitative study should be considered in order to obtain more information from respondents.
\end{abstract}

Keywords: Mathematics Achievement, Affective Engagement, Parental Involvement, Behavior Engagement, and Cognitive Engagement.

\section{Introduction}

Student achievement is an indication of students' learning and mastery outcomes. To achieve effective learning, the development of student engagement from the affective, behavioral and cognitive aspects must be emphasized (Fredricks et al., 2004). Student engagement was the solution to lower learning motivation and achievement among students (Fredrick et al., 2004). In learning mathematics at the university, a weak mastery can affect other courses that require mathematical skills. Based on this connection, a profound 
understanding of student engagement has become the prerequisite to the field of education. Previous studies (e.g., Conner, 2016; Dary et al., 2016; Fredrick et al., 2004; Gerber et al., 2013; Gunuc, 2014; Lam et al., 2016; Lee, 2014; Lei et al., 2018) have shown that there is a significant relationship between academic achievement and student engagement. Student engagement not only increases students' achievement (Schreiber \& Yu, 2016; Wang \& Degol, 2014; Williams et al., 2017) but also increases their rate of stay (Soria \& Stebleton, 2012), addresses the issue of burnout (Cazan, 2015; Salmela-Aro \& Upadyaya, 2014; Salmela-Aro. et al., 2016), and increases the quality of the learning outcome (Gunuc, 2014; Krause \& Coates, 2008; Zhang et al., 2015). Student engagement refers to the investment of efforts, time, and commitment needed throughout the learning process (Dary et al., 2016). Student engagement can ensure the acquisition of knowledge and skills taught to the students. The students concerned will pay attention to the teaching and give total commitment until the material taught will be understood (Dary et al., 2016). The increased understanding in the course taught means that the students' mastery would increase, and with that, their achievement will also increase (Sedaghat et al., 2011; Wang \& Degol, 2014).

Student engagement comprises three interconnected dimensions: behavior engagement, cognitive engagement, and affective engagement (Fredricks et al., 2004; Lam et al., 2016). Behaviour engagement refers to student involvement in the learning activity, attendance to the class, and the effort to understand the learning (Fredricks et al., 2004; Gerber et al., 2013; Gunuc \& Kuzu, 2015a). Therefore, behaviour engagement can be measured based on the participation in-class activities, the determination to understand the lesson (Gerber et al., 2013; Gunuc \& Kuzu, 2015a), commitment towards the academic tasks, and adherence with the institution regulations (Fredricks \& Mccolskey, 2012). Cognitive engagement is referred to as the improved understanding and the mastery of teaching materials (Witkowski \& Cornell, 2015). Cognitive engagement has a positive impact on selfregulation, the interest to learn (Durksen et al., 2017; Gunuc, 2014; Sedaghat et al., 2011), and students' appreciation towards the knowledge, lecturer, and learning mates (Gerber et al., 2013). Cognitive engagement can be measured by setting the learning aim, self-regulation, and appreciation towards the knowledge value (Gunuc, 2014; Greene, 2015). Next, affective engagement refers to students' responses towards the lecturer, friend, course content, or class environment (Gunuc \& Kuzu, 2015a). Affective engagement increases the students' interest and curiosity about the material taught, so they feel that it is fun to learn (Fredricks \& Mccolskey, 2012; Gerber et al., 2013). Reversibly, the reduced rate of affective engagement can cause self-isolation during teaching and learning (Conner, 2016).

\section{Mathematics Learning and Student Engagement}

The mastery of mathematics is crucial to advanced learning and critical to the vocational field and daily life. Past literature that has looked specifically into student engagement in mathematics learning (e.g., Bobis et al., 2016; Fredricks et al., 2016; Ingram, 2013; Marham et al., 2016; Rimm-Kaufman et al., 2015; Watt et al., 2017) reveals that student engagement in terms of the behaviour, cognitive and affective contributes to improved mathematics achievement. The study done by Bobis et al. (2016) shows that student engagement in mathematics learning can increase mathematics achievement. The finding from Fredricks et al. (2016) also points to the significant relationship between student engagement and Science and Mathematics achievement. This is similar to Rimm-Kaufman et al. (2015) work, where students who have engaged actively during mathematics learning and who have completed mathematics tasks are found to show better mathematics achievement. A longitudinal study 
by Ingram (2013) shows that student engagement has a relationship with the increased quality of mathematics achievement. Because students who are engaged learn more than students who are less engaged (Salim \& Ayub, 2017), active engagement in terms of behaviour, cognitive and affective ensures that mathematics knowledge and skills learned can be mastered to the maximum (Ayub et al., 2017). In that, student engagement is capable of influencing success as the outcome of mathematics learning. Given that student engagement is key to address the issue of low achievement (Fredrick et al., 2004; Shernoff et al., 2016; Shernoff et al., 2017; Wang \& Eccles, 2012a, 2012b), a good understanding of student engagement can surely benefit the society, the university, the students and the policymakers.

\section{Parental Involvement and Peer Influence}

In the learning environment, individuals other than teachers that leave an impact on student engagement are peers (Engels et al., 2016; Nguyen et al., 2016; Uzezi \& Deya, 2017; Vollet et al., 2017; Witkowski \& Cornell, 2015), and parents (Arshad \& Shahzadi, 2016; Boonk et al., 2018; Grove et al., 2020; Harper et al., 2012; Lowe \& Dotterer, 2017; Svoboda et al., 2016). This is because student engagement is a dynamic process influenced by various social factors (Wang \& Eccles, 2012a, 2012b). The more student engagement experiences related to the relationship can be understood, the more strategy to increase student achievement can be planned and practiced (Wang \& Eccles, 2012a, 2012b). An example would be the relationship between parents and students. The finding from the study of Wang and Eccles (2012b) shows that parental involvement can form student engagement as they are the agent of socialization that is the most important in the students' lives. According to the parental involvement theory by Grolnick and Slowiaczek (1994), parental involvement through behaviour, interaction, and intellect can affect students' motivation, competency, and selfregulation. However, parental involvement in children's learning is becoming less frequent when they grow (Zakaria \& Salleh, 2011). Usually, parents will think that grown children are ready to shoulder more responsibilities, make their own decisions, shape their behaviour, and handle their learning themselves. The study by Deka (2016) shows that children, be it young kids or teenagers, are always hopeful of their parents' support. The emotional, information and physical support that combine to form this parental involvement can leave an impact on their children's engagement in their learning (Lowe \& Dotterer, 2018). The work done by Arshad and Shahzadi (2016) shows that parental involvement in their children's learning at school or higher institutions is equally substantial. The finding indicates that most university students are hoping for parental involvement throughout their studies. Parental participation in monitoring, guidance, belief, and closeness is vital to guide the children to stand on their own two feet and address any issues they face in the university (Soria \& Stebleton, 2012). In short, the requirement for parental involvement in children's learning is a never-ending process, although they have gone into adulthood.

Next, we have peer influence. Peers are friends from the same age group as classmates or university mates, and they can influence student's moral development, personality formation, and behaviour (Lynch et al., 2013; Vollet et al., 2017). The study finding shows that peer influence leaves an impact on engagement. Peer influence refers to students' relationships and dependency on their friends to obtain information, learning assistance, and emotional support (Furrer et al., 2014). Past studies (e.g., Gonyea \& Kinzie, 2015; Ribera et al., 2017) show that peer influence gets stronger as students get older. The support received from peers helps students adapt to the university's environment and learning style faster. The relationship among friend influences student engagement at the university as they tend 
to share the same activities. In that vein, peer's discussion group has a substantial influence to draw student engagement towards their lessons. The finding from other past studies (e.g., Lynch et al., 2013; Molloy et al., 2011; Witskowski \& Cornell, 2015) shows that peers play an important role in students' formation' cognitive engagement and affective engagement. Other than that, peers can also influence students' achievement (Molloy et al., 2011; Uzezi \& Deya, 2017). Typically, peer influence becomes more dominant in student learning as they prefer to get help from their peers rather than their teachers (Bergey et al., 2019).

In short, parental involvement and peer influence can generate and inhibit the student engagement development in their close relationship with them. Thus, a close look at the title of the two factors cannot be made trivial. Understanding parental involvement and peer influence can increase student engagement and, further, student achievement in mathematics

\section{Objective of the Study}

In line with the expansion of the higher education sector in Malaysia, the diversity of students' backgrounds has increased the university's responsibility in ensuring the quality of students' learning outcomes. For the private universities offering study programs in science, technology, accounting, or management, some of the most significant challenges would be to ensure students' mastery of mathematics (Ismail et al., 2017; Kanafiah \& Jumadi, 2013). This is crucial, as this subject is a compulsory subject and the prerequisite for most of the university's courses (Othman et al., 2014; Nik Aziz, 2008). Simultaneously, throughout learning, students need social support from multiple resources to aid their understanding (Jelas et al., 2016; Wang \& Eccles, 2012b). Thus, this study examines the relationship between student achievement, student engagement, parental involvement, and peer influence specializing in mathematics learning. This study is essential to add value to the research related to limited student engagement, especially among private higher education in Malaysia. The questions of this study are as follows:

a) What is the relationship between parental involvement and peer influence and student engagement in mathematics learning?

b) Is there any relationship between behaviour engagement, cognitive engagement, affective engagement, parental involvement, and peer influence with mathematics achievement?

\section{Methodology \\ Study Sample}

In this study, the correlational study design was applied to identify the relationship between variables. The sample comprises students $(N=284)$ selected using the ratio stratified random sampling from all the mathematics courses offered in Malaysia's private university. Students comprise $76.8 \%$ males and $23.2 \%$ females aged between 19 and 24 years old. More than half of the sample (54.6\%) are local students, and the rest is international students (45.4\%). In terms of the father's academic qualification, $39.8 \%$ have a degree or diploma, and some have certificates (39.8\%), followed by those with a bachelor's degree (16.9\%). Most mothers have certificates (43.7\%) for the mother's academic qualification, followed by $40.8 \%$ with a degree or diploma and $9.5 \%$ with a Master's degree. 


\section{Procedure}

The study's evaluation and the instrument's adequacy are carried out through a pilot study on 77 students. The actual data collection involves 284 students from the same university. To determine the relationship between mathematics achievement, student engagement, parental involvement, and peer influence, 300 self-report questionnaires were distributed to the selected students based on the strata of the math class assigned.

\section{Measurement}

Mathematics achievement. The mathematics achievement measurement was based on the students' total marks in their respective Mathematics courses. Since the respondents were chosen based on the course strata, the achievement was measured based on their final exam marks and course work covering quiz marks, mid-semester exam marks, assignment marks, and test marks. Conclusively, the total marks were used to get an actual picture of the relationship between student engagement and mathematics achievement according to the different contents and levels of mathematics courses' difficulty (Holland-Minkley \& Lombardi, 2016). This measurement was proposed by Gerber et al (2013) as student engagement is a significant moderator between the initial evaluation (coursework marks) and the final evaluation (final examination marks).

Student engagement. This study adapts The Math and Science Engagement Scales developed by Wang et al (2016) to measure student engagement experience. The measurement was depending on behaviour engagement (e.g., "I don't participate in math class," "If I do not understand while learning math, I will give up right away"), cognitive engagement (e.g., "I do not put full effort while learning math," "I put enough effort to complete math assignments") and affective engagement (e.g., "I don't want to be in math class," "I often feel disappointed while in math class "). All the items were put forth using the Likert scale with the score range starting from " 1 " strongly disagree to " 5 " strongly agree. The internal validity for this scale was excellent $(\alpha=0.90)$.

Parental involvement and peer influence. The measurement of students' perception towards parental involvement was adapted from the study by Liu et al. (2010). Meanwhile, the measurement of peer influence was obtained from the answer to the item adapted from the study by Uzezi and Deya (2017). Students respond to this section on the 5-point Likert scale, starting from 1 (strongly disagree) to 5 (strongly agree). The internal validity for the scale of parental involvement $(\alpha=0.85)$ and peer influence $(\alpha=0.82)$ were good. The descriptive statistics for the items parental involvement and peer influence are illustrated in Table 1. 
Table 1: Descriptive Statistics $(n=284)$

\begin{tabular}{lrr}
\hline Item & Mean & SD \\
\hline $\begin{array}{l}\text { Parental Involvement } \\
\text { My parents make me believe that I can do well in math. }\end{array}$ & 4.10 & .99 \\
$\begin{array}{l}\text { My parents encourage me to keep trying when I get stuck in math } \\
\text { assignments. }\end{array}$ & 3.97 & 1.05 \\
$\begin{array}{l}\text { My parents encourage me to have a positive attitude towards math } \\
\text { assignments. }\end{array}$ & 4.11 & .98 \\
$\begin{array}{l}\text { My parents ask me to get help when a math problem is hard to be solved. } \\
\text { My parents ask me to communicate with the math lecturer when I have }\end{array}$ & 3.82 & 1.12 \\
$\begin{array}{l}\text { math questions. } \\
\text { Peer Influence }\end{array}$ & & 1.07 \\
$\begin{array}{l}\text { My math understanding is better when I study with my friends. } \\
\text { My current math achievement is better when I study with friends }\end{array}$ & 3.87 & 1.01 \\
$\begin{array}{l}\text { compared to when I do it alone. } \\
\text { Ilearn more in math while doing exercises with my friends compared to } \\
\text { when I do alone. }\end{array}$ & 3.54 & 1.08 \\
\hline
\end{tabular}

\section{Result}

Data analysis was divided into two sub-sections. In the first section, the descriptive analysis was used to explain mathematics marks distribution. In the second section, the multiple regression analysis with the stepwise regression method was used to generate the regression model between mathematics achievement (dependent variable) and behavior engagement, cognitive engagement, affective engagement, peer influence, and parental involvement (independent variables). Through the stepwise regression method, every independent variable's contribution rate was calculated, and the regression model formed based on the highest contribution (Huck, 2012).

Figure 1 shows the mathematics marks distribution that represents the mathematics achievement among the students in the university. The average mark was 55.60 (SP = 19.46), with skewness of $-0.103 \mathrm{~s}$, showing that the students' distributed marks are close to normal. In the context of the university being studied, the students' mathematics achievement was at a moderate level. A range of marks between 55 and 59 are categorized as grade $\mathrm{C}+$. It was found that $58.8 \%$ of the students got marks below 60 while $14 \%$ of them getting marks 39 and below.

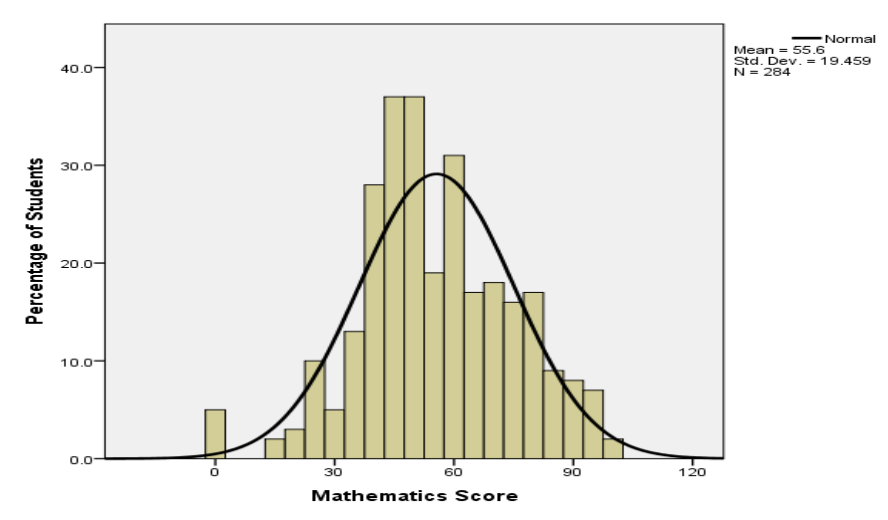

Figure 1. Distribution of Mathematics Marks 
Table 2 shows the results of the correlation and the descriptive analysis for the study variables.

Table 2. Correlation Value, Mean, Standard Deviation of Variables

\begin{tabular}{lccccccc}
\hline Variables $(\mathbf{n}=\mathbf{2 8 4})$ & 1 & 2 & 3 & 4 & 5 & 6 & 7 \\
\hline 1. Mathematics Achievement & 1 & .020 & $.152^{* *}$ & $.155^{* *}$ & $-.146^{*}$ & $-.153^{* *}$ & $.147^{*}$ \\
2. Behavioural Engagement & & 1 & $.557^{* *}$ & $.365^{* *}$ & $.212^{* *}$ & $.139^{*}$ & $.669^{* *}$ \\
3. Cognitive Engagement & & & 1 & $.462^{* *}$ & .031 & $.246^{* *}$ & $.783^{* *}$ \\
4. Affective Engagement & & & & 1 & $-.172^{*}$ & .042 & $.885^{* *}$ \\
5. Parental Involvement & & & & & 1 & $.150^{*}$ & -.047 \\
6. Peer Influence & & & & & & 1 & $-.148^{*}$ \\
7. Student Engagement & & & & & & & 1 \\
Mean & 55.60 & 3.13 & 3.29 & 2.11 & 4.00 & 3.73 & 2.81 \\
SD & 19.46 & 1.43 & 1.34 & 1.20 & 1.05 & 1.06 & 1.42 \\
\hline
\end{tabular}

${ }^{*} p<.05,{ }^{* *} p<.01$

Referring to Table 2, most variables are related significantly and positively to mathematics achievement except for behaviour engagement. Meanwhile, there is a significant and negative relationship between mathematics achievement, and peer influence and the relationship between mathematics achievement and parental involvement. Based on the mean value obtained, all in all, student engagement is at a moderate level $(M=2.81, S D$ $=1.42)$. The level of behaviour engagement $(M=3.13, S D=1.43)$ and cognitive engagement $(M=3.29, S D=1.34)$ are also moderate, whereas affective engagement stays at low level ( $M$ $=2.11, \mathrm{SD}=1.20)$. The mean value shows that mathematics achievement among students is at a moderate level $(M=55.60, S D=19.46)$, and this sits well with the moderate level of student engagement in mathematics learning. In the meantime, for parental involvement ( $M$ $=4.00, \mathrm{SD}=1.05)$ and peer influence $(\mathrm{M}=3.73, \mathrm{SD}=1.06)$, students show a positive perception towards both factors.

For the items that measure student engagement, most students agree that they have re-checked the assignments they have done and made sure that it is correct before they submit it. They have also done the best in every task and work hard in completing the mathematics assignments. In terms of parental involvement, most of them agree that parents play a role in shaping their positive attitude toward the tasks at hand (Table 1). Parental involvement also renews their faith that they can score well in Mathematics. The parents even always encourage them to communicate with their lecturer concerning mathematics learning. Based on this finding, it can be stated that parents' concern towards the children's learning issue and performance influences their engagement towards learning. Concurrently, in terms of peer influence, most students agree that their mathematical understanding becomes better when they learn with friends than learning alone. They can also get to study more when they do exercises in a group. Also, learning with friends increases their mathematics performance. 
Table 3 shows the results of the correlation between the variable and mathematics achievement.

Table 3. Pearson Correlation Value between Predicting Variable and Mathematics Achievement

\begin{tabular}{|c|c|c|c|c|c|c|c|}
\hline & & \multicolumn{3}{|c|}{ Student Engagement } & \multirow{2}{*}{$\begin{array}{c}\text { Parental } \\
\text { Involvement }\end{array}$} & \multirow{2}{*}{$\begin{array}{c}\text { Peer } \\
\text { Influence }\end{array}$} & \multirow{2}{*}{$\begin{array}{c}\text { Overall } \\
\text { Engagement }\end{array}$} \\
\hline & & Behaviour & $\begin{array}{c}\text { Cognitiv } \\
\mathrm{e}\end{array}$ & $\begin{array}{c}\text { Affectiv } \\
\text { e }\end{array}$ & & & \\
\hline Mathematic & $r$ & .020 & $.152^{* *}$ & $.155^{* *}$ & $-.146^{*}$ & $-.153^{* *}$ & $.147^{*}$ \\
\hline $\begin{array}{l}\mathrm{s} \\
\text { Achievemen } \\
\mathrm{t}\end{array}$ & $p$ & .739 & .010 & .009 & .013 & .010 & .013 \\
\hline
\end{tabular}

Based on the result in Table 3, there is a direct and significant relationship between mathematics achievement and student engagement $(r=.147, p<.05)$, cognitive engagement $(r=.152 p<.05)$, affective engagement $(r=.155, p<.05)$, parental involvement $(r=-.146, p$ $<.05)$, and peer influence $(r=-.153, p<.05)$. Despite the insignificant relationship between mathematics achievement and behaviour engagement $(r=.020, p>.05)$, but it is stated that there is an indirect relationship between mathematics achievement and behaviour engagement. This goes well with the finding shown in table 4 where there is a correlation between behaviour engagement and student engagement in mathematics learning as a whole $(r=.669, p<.01)$. This finding shows that the concentration on development of parental involvement, peer influence, behaviour engagement, cognitive engagement and affective engagement are indispensable to increase mathematics achievement.

Student engagement has a significant effect on mathematics achievement (Table 3). The development of student engagement can increase mathematics achievement has been proven in many previous studies (e.g., Bobis et al., 2016; Fredricks et al., 2016; Ingram, 2013; Marham et al., 2016; Rimm-Kaufman et al., 2015; Watt et al., 2017). The increased student engagement enables the students to master more mathematics things (Ayub et al., 2017). This study shows that student engagement in mathematics learning is at a moderate level, which agrees with several results from past studies toward students in Malaysia (e.g., Ayub et al., 2017; Salim \& Ayub et al., 2017). However, the moderate level of engagement in mathematics learning between school students and university students is different. For instance, Ayub et al. (2017) study that secondary school students' highest engagement is in the behavioral aspect, followed by cognitive engagement, and the next is affective engagement. While the moderate level of engagement of students at the public university is dominated by behaviour engagement, then affective engagement, and afterward cognitive engagement (Salim \& Ayub, 2017). For the present, this study's finding shows the moderate level of engagement among private university students is most influenced by cognitive engagement, followed by behaviour engagement, and finally, affective engagement.

\section{Parental Involvement}

The study finding shows that parental involvement has a negative and significant relationship with mathematics achievement, indicating that increased parental involvement can reduce their children's mathematics achievement level. Nevertheless, all in all, the majority of the students have a positive perception of their parental involvement. They 
appreciate their parental involvement be it physically, instrumentally, through information or advice. This finding is congruous with that of Arshad and Shahzadi (2016). They find that most university students welcome their parental involvement in learning, but they also feel the need to have some freedom in certain areas. They hope that their parents can give them the space to arrange their lives in their way, including making decisions that they think are right (Arshad \& Shahzadi, 2016).

According to the Self-Determination Theory by Deci and Ryan (1985, 2000), student competency is interconnected with autonomy. Thus, a significant relationship between parental involvement and mathematics achievement obtained in this study illustrates that the relationship and autonomy-granting aspect can motivate the students and further propel them to succeed in their learning. By way of explanation, the students selected for this study are 23 years of age on average - they have already passed their teenage years. There have already been aware of their role as children who should obey their parents (Syed \& SeiffgeKrenke, 2013). Students at this age also seek support in the form of autonomy, privacy, and freedom that are deemed appropriate and reasonable. As we refer to the demographic findings, the majority of parents have a diploma and above. Usually, these highly educated parents will hope for their children to excel academically (Svoboda et al., 2016). Parents' high involvement, such as excessive monitoring, pressurizes the students, which affects their learning. This may be the factor for the negative relationship between parental involvement and mathematics achievement among students.

To conclude, parental involvement in their children is crucial at all study levels (Jelas et al., 2016; Mehdinezhad, 2011). Although there is a drop in parental involvement because learning is more difficult and more challenging (Abd Razak Zakaria \& Noraini Mohd Salleh, 2011), this study has proven that parental involvement is essential for academic and social pressures at the university. Even more so, parental participation in support and motivation can influence the children's perception of the learning institution and their behavior in class, and their learning engagement (Arshad \& Shahzadi, 2016; Lowe \& Dotterer, 2018).

\section{Peer Influence}

The study finding shows a negative and significant relationship between peer influence and mathematics achievement (Table 3 ) and the relationship between peer influence and student engagement (Table 2). This finding shows that peers directly affect mathematics achievement and an indirect effect on mathematics achievement through student engagement. A negative relationship indicated that the increased peer influence shows a deteriorating impact on mathematics achievement and student engagement. This finding is at par with previous studies (e.g., Lynch et al., 2013; Vollet et al., 2017) that finds that peer influence is higher on friends who are less engaged with the lecturer. Peer influence is more significant during difficult subjects' learning (Furrer et al., 2014). Students' dependency on their friends in understanding the lesson can negatively impact their friends' engagement through distraction in class. Thus, peers have the most impact on student's behaviour engagement (Wang \& Eccles, 2012b). Students always see their friends as the most vital resource to get information and learning aid other than the lecturer (Molloy et al., 2011). As they share many of the same activities, the close relationship with their peers influences their friends' behaviour in learning. Still, they are also able to influence their lifestyle at the university. Peer influence is also more substantial on students at a higher level of understanding than school students (Molloy et al., 2011). 
On the other hand, the study by Kessels et al. (2014) establishes that this reduced achievement of male students caused by peer influence is linked with adherence to the regulations like not attending classes, late submission of assignments, and failure complete assignments. Thus, the high percentage of the male students in this study may clarify the moderate mathematics achievement among the students. This statement indicates that $63.7 \%$ of the students of this study had submitted incomplete mathematics assignments.

Although students at the university level are supposed to have mature thinking, attitude, and emotions, this study's finding informs us that peer influence can significantly affect student engagement and their achievement in learning. In terms of students' perception of peer influence, most students admit that friends help with their mathematics learning. They state that their mathematical understanding is better when they learn with friends. They also agree that doing exercises with friends do increase their mastery and skills in mathematics. Even more so, their mathematics achievement also increases after they learn with their friends.

\section{Relationship between Mathematics Achievement, Student Engagement, Parental Involvement, and Peer Influence}

The stepwise method's regression analysis was carried out to determine the extent to which three dimensions of student engagement, parental involvement, and peer influence can predict mathematics achievement. Table 4 shows that the best model is obtained at the fourth step with the $t$-value for the predictor variable is significant $(p<.05)$. The most influential variable to mathematics achievement is affective engagement $(\beta=3.748, p<.01)$, followed by parental involvement $(\beta=-5.228, p=.000)$, then behaviour engagement $(\beta=$ $8.332, p<.01)$, and lastly cognitive engagement $(\beta=6.524, p<.01)$. The regression analysis outcome shows that all four variables can explain in a significant way $10 \%$ of the variance of mathematics achievement among the students $\left(R^{2}=.10, p=.000\right)$. The ANOVA test results reveal that the model produced is significant and can be applied $(F(4,279)=7.500, p=.000)$.

Table 4. Multiple Regression Analysis Results

\begin{tabular}{clrcrrl}
\hline Model & Variable & \multicolumn{1}{c}{$\beta$} & SE & Beta & \multicolumn{1}{c}{$t$} & \multicolumn{1}{c}{$p$} \\
\hline 1 & (Constant) & 61.899 & 2.656 & & 23.309 & .000 \\
& Affective Engagement & 2.981 & 1.135 & .155 & 2.627 & .009 \\
\hline 2 & (Constant) & 79.635 & 6.417 & & 12.411 & .000 \\
& Affective Engagement & 3.571 & 1.135 & .185 & 3.145 & .002 \\
& Parental Involvement & -4.127 & 1.363 & -.178 & -3.027 & .003 \\
\hline 3 & (Constant) & 69.573 & 7.569 & & 9.192 & .000 \\
& Affective Engagement & 4.837 & 1.238 & .251 & 3.906 & .000 \\
& Parental Involvement & -5.166 & 1.416 & -.223 & -3.648 & .000 \\
& Behaviour Engagement & 5.390 & 2.198 & .159 & 2.452 & .015 \\
\hline \multirow{2}{*}{4} & (Constant) & 79.780 & 8.432 & & 9.462 & .000 \\
& Affective Engagement & 3.748 & 1.293 & .194 & 2.898 & .004 \\
& Parental Involvement & -5.228 & 1.401 & -.226 & -3.731 & .000 \\
& Behaviour Engagement & 8.332 & 2.445 & .245 & 3.408 & .001 \\
& Cognitive Engagement & 6.524 & 2.475 & .192 & 2.636 & .009 \\
\hline
\end{tabular}

$R=.312, R^{2}=.097 . F=7.500, p=.000$ 
Thus, the regression equation produced is mathematics achievement $=79.780+($ affective engagement $* 3.748)+($ parental involvement $*-5.228)+($ behaviour engagement $* 8.332)+$ (cognitive engagement $* 6.524$ ).

\section{Discussion}

On the whole, the finding shows that student engagement and parental involvement can increase mathematics achievement. The development of affective engagement, behaviour engagement, and cognitive engagement must be stressed to develop private university students' engagement in mathematics learning. The current study reveals that the influence of private university students' student engagement dimension is different from school students and public university students. This study finding shows that the development of affective engagement is vital to increase mathematics achievement. However, the development of engagement in terms of behaviour and cognitive also required as all dimensions are interconnected. Thus, based on the current finding, a different strategy needs to be planned according to the student cohort (school, public university, private university) to develop student engagement, although all three dimensions influence mathematics achievement. This finding contributes essential knowledge to the concerned parties involved in planning mathematics education strategy, especially in private universities. This is explained by the fact that almost all the programs in universities require students to take at least one mathematics course throughout their studies (Deeken et al., 2020). Besides, a lot of engineering and science programs at these private universities require students to master mathematics. Given that student engagement is the solution to increasing mathematics achievement (Barkley \& Major, 2020; Bobis et al., 2016; Fredricks et al., 2016; Ingram, 2013; Rimm-Kaufman et al., 2015; Watt et al., 2017), the development of student engagement becomes pivotal. This enables students to master other courses that require mathematical skills (Salim \& Ayub, 2017; Conduit et al., 2016; Maron, 2016; Wang \& Degol, 2014).

This study also shows that parental involvement at the university level plays an essential role in mathematics learning. Students' positive perception of parental involvement gives the picture that they welcome their parental participation in their learning. Parental participation in support motivates the children not to handle challenges with mathematics learning at the university. This study finds that meaningful communication between parents and students affects student engagement. Parental involvement in the form of motivation, guidance, and advice is crucial to retain student engagement. Although the students are already adults, they still need guidance from their parents to learn. Based on this study's finding, the university is suggested to establish a close bond between parents and students by organizing activities and programs involving both parties. Good, meaningful communication between parents and their children can ensure that students stay engaged in their learning. This study also discovers that peers have direct and indirect influences on students' mathematics achievement. Peers who are the sources of information and guidance to students' learning play a significant role in student engagement development. This study suggests that there should be more group learning activities to increase students' engagement and achievement in mathematics. This suggestion is based on students' positive perception of peer influence concerning their engagement and mathematics learning performance.

\section{Practical Implication}

This study contributes to the literature related to affective engagement, behaviour engagement, and parental involvement as the predictor of mathematics achievement. 
Student engagement is the best way to address the deteriorating mathematics achievement among private university students. The focus on developing affective engagement should be emphasized to form behaviour engagement and cognitive engagement among students. Implementing a program that can increase parental involvement in children's learning at the university can also increase student engagement. This study proposes that the university improves the existing $\mathrm{m}$-learning system by involving parents in the learning activity and their children's development and progress. As for the peers' role, further detailed studies are needed on the relationship between peer influence and student engagement. This is based on the peer influence towards mathematics achievement that can be explained through student engagement in mathematics learning.

\section{References}

Zakaria, A. R., \& Salleh, N. M. (2011). Konteks keluarga dan hubungannya dengan penglibatan ibu bapa dalam pendidikan anak-anak di sekolah menengah. Jurnal Pendidikan Malaysia, 36(1), 35-44.

Arshad, M., \& Shahzadi, E. (2016). Parents involvement at university level education: students perception in under developing country. European Scientific Journal, 12(22), 294-304. https://doi.org/10.19044/ esj.2016.v12n22 p294

Ayub, A. F. M., Yunus, A. S. M., Mahmud, R., Salim, N. R., \& Sulaiman, T. (2017, January). Differences in students' mathematics engagement between gender and between rural and urban schools. In AIP Conference Proceedings (Vol. 1795, No. 1, p. 020025). AIP Publishing LLC. https://doi.org/ 10.1063/1.4972169

Barkley, E. F., \& Major, C. H. (2020). Student engagement techniques: A handbook for college faculty. John Wiley \& Sons.

Bergey, B. W., Parrila, R. K., Laroche, A., \& Deacon, S. H. (2019). Effects of peer-led training on academic self-efficacy, study strategies, and academic performance for first-year university students with and without reading difficulties. Contemporary Educational Psychology, 56, 25-39. https://doi.org/10.1016/j.cedpsych.2018.11.001

Bobis, J., Way, J., Anderson, J., \& Martin, A. J. (2016). Challenging teacher beliefs about student engagement in mathematics. Journal of Mathematics Teacher Education, 19(1), 33-55. https://doi.org/10.1007/s10857-015-9300-4

Boonk, L., Gijselaers, H. J., Ritzen, H., \& Brand-Gruwel, S. (2018). A review of the relationship between parental involvement indicators and academic achievement. Educational Research Review, 24, 10-30. https://doi.org/10.1016/j.edurev.2018.02.001

Cazan, A. M. (2015). Learning motivation, engagement and burnout among university students. Procedia-Social and Behavioral Sciences, 187, 413-417. https://doi.org/10.1016/ j.sbspro.2015. 03.077

Conduit, J., Karpen, I. O., \& Farrelly, F. (2016). Student engagement: A multiple layer phenomenon. In C. Plewa and J. Conduit (eds.), Making a Difference Through Marketing (pp. 229-245). Springer Verlag. https://doi.org/10.1007/978 -981-10-0464-3

Conner, T. (2016). Relationships: The key to student engagement. International Journal of Education and Learning, 5(1), 13-22. http://dx.doi.org/10.14257/ijel.2016.5.1.02

Dary, T., Pickeral, T., Shumer, R., \& Williams, A. (2016). Weaving student engagement into the core practices of schools. A national dropout prevention center/network position paper. National Dropout Prevention Center/Network.

Deci, E. L., \& Ryan, R. M. (1985). Intrinsic Motivation and Self-Determination in Human Behavior. Plenum Press. https://doi.org/10.2307/2070638 
Deci, E. L., \& Ryan, R. M. (2000). The "what" and "why" of goal pursuits: Human needs and the self-determination of behavior. Psychological inquiry, 11(4), 227-268. https://doi.org/ 10.1207/S15327965PLI1104

Deeken, C., Neumann, I., \& Heinze, A. (2020). Mathematical Prerequisites for STEM Programs: What do University Instructors Expect from New STEM Undergraduates?. International Journal of Research in Undergraduate Mathematics Education, 6(1), 23-41. https://doi.org/10.1007/s40753-019-00098-1

Deka, P. P. (2016). A study on parental involvement in higher level of education: Voices of parents and students in Pub-Kamrup College and Patidarrang College, Kamrup district. The Clarion-International Multidisciplinary Journal, 5(1), 57-64. https://doi.org/ 10.5958/2277-937X.2016.00009.5

Dogan, U. (2015). Student engagement, academic self efficacy, and academic motivation as predictors of academic performance. The Anthropologist, 20(3), 553-561. https://doi.org/10.1080/09720073.2015.11891759

Durksen, T. L., Way, J., Bobis, J., Anderson, J., Skilling, K., \& Martin, A. J. (2017). Motivation and engagement in mathematics: A qualitative framework for teacher-student interactions. Mathematics Education Research Journal, 29(2), 163-181. https://doi.org/10. 1007/s13394-017-0199-1

Engels, M. C., Colpin, H., Van Leeuwen, K., Bijttebier, P., Van Den Noortgate, W., Claes, S., Goossens, L., \& Verschueren, K. (2016). Behavioral engagement, peer status, and teacher-student relationships in adolescence: A Longitudinal study on reciprocal influences. Journal of Youth and Adolescence, 45(6), 1192-1207. https://doi.org/10.1007/s10964-016-0414-5

Fredricks, J. A., Blumenfeld, P. C., \& Paris, A. H. (2004). School engagement: Potential of the concept, state of the evidence. Review of Educational Research, 74(1), 59-109. https://doi.org/10.3102/00346543074 001059

Fredricks, J. A., \& McColskey, W. (2012). The measurement of student engagement: A comparative analysis of various methods and student self-report instruments. In Handbook of research on student engagement, 763-782. Springer. https://doi.org/10. 1007/978-1-4614-2018-7

Fredricks, J. A., Wang, M. T., Linn, J. S., Hofkens, T. L., Sung, H., Parr, A., \& Allerton, J. (2016). Using qualitative methods to develop a survey measure of math and science engagement. Learning and Instruction, 100(43), 5-15. https://doi.org/10.1016/j.learninstruc.2016.01. 009

Furrer, C. J., Skinner, E. A., \& Pitzer, J. R. (2014). The influence of teacher and peer relationships on students' classroom engagement and everyday motivational resilience. National Society for the Study of Education, 113(1), 101-123.

George, D., \& Mallery, M. (2003). Using SPSS for Windows step by step: a simple guide and reference. Allyn \& Bacon.

Gerber, C., Mans-kemp, N., \& Schlechter, A. (2013). Investigating the moderating effect of student engagement on academic performance. Acta Academica, 45(4), 256-274.

Gonyea, R. M., \& Kinzie, J. (2015). Independent colleges and student engagement : descriptive analysis by institutional type. A 2015 National Survey of Student Engagement (NSSE) Special Analysis for the Council of Independent Colleges. Council of Independent Colleges.

Greene, B. A. (2015). Measuring Cognitive Engagement With Self-Report Scales: Reflections From Over 20 Years of Research. Educational Psychologist, 50(1), 14-30. 
https://doi.org/10.1080/ 00461520.2014.989230

Grolnick, W. S., \& Slowiaczek, M. L. (1994). Parents' involvement in children's schooling : A multidimensional conceptualization and motivational model. Child Development, 65(1), 237-252. https://doi.org/10.2307/1131378

Grove, M., Guiry, S., \& Croft, T. (2020). Specialist and more-able mathematics students: understanding their engagement with mathematics support. International Journal of Mathematical Education in Science and Technology, 51(5), 643-668.

Gunuc, S. (2014). The relationships between student engagement and their academic achievement. International Journal on New Trends in Education and Their Implications, 5(4), 216-231.

Gunuc, S., \& Kuzu, A. (2015a). Confirmation of campus-class-technology model in student engagement: A path analysis. Computers in Human Behavior, 48, 114-125. https://doi.org/ 10.1016/j.chb.2015.01.041

Hair, J. F., Black, W. C., Babin, B. J., \& Anderson, R. E. (2010). Multivariate data analysis $\left(7^{\text {th }}\right.$ ed.). Pearson Prentice Hall.

Harper, C. E., Sax, L. J., \& Wolf, D. S. S. (2012). The role of parents in college students' sociopolitical awareness, academic, and social development. Journal of Student Affairs Research and Practice, 49(2), 137-156. https://doi.org/10.1515/jsarp-2012-6147

Huck, S. (2012). Reading statistics and research (6. ed.). Boston: Pearson.

Ingram, N. (2013). Mathematical engagement skills. Mathematics Education Research Group of Australasia. 402-409.

Jelas, Z. M., Azman, N., Zulnaidi, H., \& Ahmad, N. A. (2016). Learning support and academic achievement among Malaysian adolescents: the mediating role of student engagement. Learning Environments Research, 19(2), 221-240. https://doi.org/10.1007/s10984-0159202-5

Kanafiah, S. F. H. M., \& Jumadi, A. (2013, December). Students' perception towards mathematics: attitudes, interests and lecturers' teaching. In International Symposium on Mathematical Sciences and Computing Research, 6-7.

Kessels, U., Heyder, A., Latsh, M., \& Hannover, B. (2014). How gender differences in academic engagement relate to students' gender identity. Educational Research, 56(2), 220-229. http://dx.doi.org/10.1080/00131881.2014.898916

Krause, K. L., \& Coates, H. (2008). Students' engagement in first-year university. Assessment and Evaluation in Higher Educations, 33(5), 493-505. https://doi.org/10.1080/ 02602930701698892

Lam, S. F., Jimerson, S., Shin, H., Cefai, C., Veiga, F. H., Hatzichristou, C., Polychroni, F., Kikas, E., Wong, B.P., Stanculescu, E., \& Basnett, J. (2016). Cultural universality and specificity of student engagement in school: The results of an international study from 12 countries. British Journal of Educational Psychology, 86(1), 137-153. https://doi.org/10.1111/bjep. 12079

Lee, J. -S. (2014). The relationship between student engagement and academic performance: Is it a myth or reality? The Journal of Educational Research, 107(3), 177-185. https://doi.org/10.1080/00220671.2013.

Lei, H., Cui, Y., \& Zhou, W. (2018). Relationships between student engagement and academic achievement: A meta-analysis. Social Behavior and Personality: an international journal, 46(3), 517-528. https://doi.org/10.2224/sbp.7054

Liu, F., Black, E., Algina, J., Cavanaugh, C., \& Dawson, K. (2010). The validation of one parental involvement measurement in virtual schooling. Journal of interactive online learning, 
9(2), 105-132.

Lowe, K., \& Dotterer, A. M. (2018). Parental involvement during the college transition: a review and suggestion for its conceptual definition. Adolescent Research Review, 3(1), 29-42. https://doi.org/10.1007/s40894-017-0058-z

Lynch, A. D., Lerner, R. M., \& Leventhal, T. (2013). Adolescent academic achievement and school engagement: An examination of the role of school-wide peer culture. Journal of Youth and Adolescence, 42(1), 6-19. https://doi.org/10.1007/s10964-012-9833-0

Marham, M. A., Mohd Ayub, A. F., \& Ahmad Tarmizi, R. (2016). Keterlibatan murid kolej vokasional berpencapaian rendah dalam pengajaran dan pembelajaran Matematik

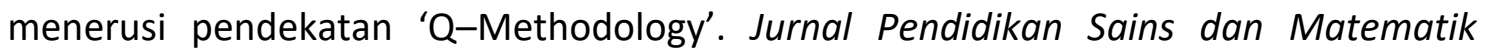
Malaysia (JPSMM UPSI), 6(1), 41-57.

Maron, A. I. (2016). Priorities of teaching mathematics in universities. International Electronic Journal of Mathematics Education, 11(9), 3339-3350.

Mehdinezhad, V. (2011). First year students ' engagement at the university. International Online Journal of Educational Sciences, 3(1), 47-66.

Molloy, L. E., Gest, S. D., \& Rulison, K. L. (2011). Peer influences on academic motivation: Exploring multiple methods of assessing youths' most "Influential" peer relationships. The Journal of Early Adolescence, 31(1), 13-40. http://www.dx.doi.org/10.1177/ 0272431610384487

Nguyen, T. D., Cannata, M., \& Miller, J. (2016). Understanding student behavioral engagement: Importance of student interaction with peers and teachers. The Journal of Educational Research, 111(2), 163-174. http://dx.doi.org/10.1080/00220671.2016.12203 59

Othman, N., Zakaria, E., \& Iksan, Z. (2014). Nilai dalam pengajaran matematik di institusi pengajian tinggi. Jurnal Penyelidikan Dan Inovasi, 1(2), 56-68.

Pallant, J. (2010). SPSS survival manual: A step by step guide to data analysis using SPSS $\left(4^{\text {th }}\right.$ ed.). Open University Press.

Reyes, M. R., Brackett, M. A., Rivers, S. E., White, M., \& Salovey, P. (2012). Classroom emotional climate, student engagement, and academic achievement. Journal of educational psychology, 104(3), 700-712. https://doi.org/10.1037/ a0027268

Ribera, A. K., Miller, A. L., \& Dumford, A. D. (2017). Sense of peer belonging and institutional acceptance in the first year: The role of high-impact practices. Journal of College Student Development, 58(4), 545-563. https://doi.org/10. 1353/csd.2017.0042

Rimm-Kaufman, S. E., Baroody, A. E., Larsen, R. A., Curby, T. W., \& Abry, T. (2015). To what extent do teacher-student interaction quality and student gender contribute to fifth graders' engagement in mathematics learning? Journal of Educational Psychology, 107(1), 170. http://dx.doi.org/ 10.1037/a0037252

Salim, N. R., \& Ayub, A. F. M. (2017). Relationship between mathematics statistics engagement and attitudes towards statistics among undergraduate students in Malaysia. In AIP Conference Proceedings (Vol. 1795, No. 1, p. 020026). AIP Publishing LLC. https://doi. org/10.1063/1.4972170

Salmela-Aro, K., Moeller, J., Schneider, B., Spicer, J., \& Lavonen, J. (2016). Integrating the light and dark sides of student engagement using person-oriented and situation-specific approaches. Learning and Instruction, 43, 61-70.

https://doi.org/10.1016/j.learninstruc. 2016.01.001 
Salmela-Aro, K., \& Upadyaya, K. (2014). School burnout and engagement in the context of demands-resources model. British Journal of Educational Psychology, 84(1), 137-151. https://doi.org/10.1111/bjep.12018

Schreiber, B., \& Yu, D. (2016). Exploring student engagement practises at a South African university: Student engagement as reliable predictor of academic performance. South African Journal of Higher Education, 30(5), 157-175. https://doi.org/10.20853/30-5593

Sedaghat, M., Abedin, A., Hejazi, E., \& Hassanabadi, H. (2011). Motivation, cognitive engagement, and academic achievement. Procedia-Social and Behavioral Sciences, 15, 2406-2410. https://doi.org/10.1016/j.sbspro.2011.04.117

Shernof, D. J., Ruzek, E. A., Sannella, A. J., Schorr, R. Y., Sanchez-Wall, L., \& Bressler, D. M. (2017). Student engagement as a general factor of classroom experience: Associations with student practices and educational outcomes in a university gateway course. Frontiers in psychology, 994(8), 1-23. https://doi.org/10.3389/fpsyg.2017.00994

Shernoff, D. J., Kelly, S., Tonks, S. M., Anderson, B., Cavanagh, R. F., Sinha, S., \& Abdi, B. (2016). Student engagement as a function of environmental complexity in high school classrooms. Learning and Instruction, 43, 52-60.

Skilling, K., Bobis, J., \& Martin, A. J. (2020). The "ins and outs" of student engagement in mathematics: shifts in engagement factors among high and low achievers. Mathematics Education Research Journal, 1-25.

Soria, K. M., \& Stebleton, M. J. (2012). First-generation students' academic engagement and retention. Teaching in Higher Education, 17(6), 673-685. https://doi.org/10.1080/ 13562517.2012.666735

Svoboda, R. C., Rozek, C. S., Hyde, J. S., Harackiewicz, J. M., \& Destin, M. (2016). Understanding the relationship between parental education and STEM course taking through identitybased and expectancy-value theories of motivation. AERA Open, 2(3), 1-13. https://doi.org/10.1177/2332858416664875

Syed, M., \& Seiffge-Krenke, I. (2013). Personality development from adolescence to emerging adulthood: Linking trajectories of ego development to the family context and identity formation. Journal of personality and social psychology, 104(2), 371-384. https://dx.doi.org/10.1037/a0030070

Tabachnick, B. G., \& Fidell, L. S. (2013). Using multivariate statistics ( $6^{\text {th }}$ ed.). Allyn and Bacon. Uzezi, J. G., \& Deya, G. D. (2017). Relationship between peer group influence and students' academic achievement in Chemistry at secondary school level. American Journal of Educational Research, 5(4), 350-356. https://doi.org/10.12691/education-5-4-2

Vollet, J. W., Kindermann, T. A., \& Skinner, E. A. (2017). In peer matters, teachers matter: Peer group influences on students? engagement depend on teacher involvement. Journal of Educational Psychology, 109(5), 635-652. https://doi.org/10. 1037/edu0000172

Wang, C. J., Liu, W. C., Kee, Y. H., \& Chian, L. K. (2019). Competence, autonomy, and relatedness in the classroom: understanding students' motivational processes using the self-determination theory. Heliyon, 5(7), e01983.

https://doi.org/10.1016/j.heliyon.2019. e01983

Wang, M. T., \& Degol, J. (2014). Staying engaged: Knowledge and research needs in student engagement. Child Development Perspectives, 8(3), 137-143. https://doi.org/10.1111/ cdep.12073

Wang, M. T., \& Eccles, J. S. (2012a). Adolescent behavioral, emotional, and cognitive engagement trajectories in school and their differential relations to educational 
success. Journal of Research on Adolescence, 22(1), 31-39.

https://doi.org/10.1111/j.15327795. 2011.00753.x

Wang, M. T., \& Eccles, J. S. (2012b). Social support matters: Longitudinal effects of social support on three dimensions of school engagement from middle to high school. Child Development, 83(3), 877-895. https://doi.org/10.1111/j.1467-8624.2012.01745.x

Wang, M. T., Fredricks, J. A., Ye, F., Hofkens, T. L., \& Linn, J. S. (2016). The math and science engagement scales: Scale development, validation, and psychometric properties. Learning and Instruction, 43, 16-26.

https://doi.org/10.1016/j.learninstruc.2016.01.008

Wang, M. T., Willett, J. B., \& Eccles, J. S. (2011). The assessment of school engagement: Examining dimensionality and measurement invariance by gender and race/ethnicity. Journal of School Psychology, 49(4), 465-480. https://doi.org/10.1016/j.jsp.2011.04. 001

Watt, H. M., Carmichael, C., \& Callingham, R. (2017). Students' engagement profiles in mathematics according to learning environment dimensions: Developing an evidence base for best practice in mathematics education. School Psychology International, 38(2), 166-183. https://doi.org/10.1177/0143034316688373

Williams, E. A., Zwolak, J. P., Dou, R., \& Brewe, E. (2017). Engagement, integration, involvement: supporting academic performance and developing a classroom social network. arXiv preprint arXiv:1706.04121.

Witkowski, P., \& Cornell, T. (2015). An Investigation into Student Engagement in Higher Education Classrooms. InSight: A Journal of Scholarly Teaching, 10, 56-67.

Zhang, Z., Hu, W., \& McNamara, O. (2015). Undergraduate student engagement at a Chinese university: A case study. Educational Assessment, Evaluation and Accountability, 27(2), 105-127. https://doi.org/10.1007/s11092-015-9213-x 